\title{
CRIANÇA E POESIA, NA PEDAGOGIA FREINET
}

Ieda Teresinha GOUVÊ**

A autora Gloria Kirinus num agradável e saboroso passeio pelo enredo e buliço - se quiserem, mais ludicamente, pelas traquinagens - da educação, afirma e discute "o inatismo da linguagem no homem", ao que acrescento, com seu próprio suporte "o inatismo poético da linguagem do homem".

Desde o prefácio de Francisca da Nóbrega, têm-se a alegria e a emoção como motoras e constituintes fundamentais da vida e do processo educativo, onde 0 "processo de viver é sempre o mesmo: constatar registrando, organizar categorizando e escolher situando-se".

É na afirmação das razões do amor que move o profissional - de qualquer área - para o desempenho político de seu fazer diário que recupera a possibilidade do belo no espaço-exercício da seriedade. Belo esse muito mais necessário e emocionante, resistente e instigante quando se trata da educação. Em outras palavras, na beleza do discurso acadêmico de Kirinus, na conspiração das palavras, percebe-se claramente o espaço para a existência do poeticamente poético do fazer educativo. Ainda Nóbrega, sobre o trabalho de Kirinus, afirma (e nós concordamos) que “...todos nascemos com o poder de representar. E o supremo crime contra o ser humano é interditar esse poder". Poder esse centrado no inatismo da linguagem, como tantas vezes afirma a autora.

Trata-se, nesta obra, de verificar a linguagem, língua e discurso do professor. Não do discurso da escola pura e simplesmente, mas do discurso daqueles que fazem a escolha pela mediação do conhecimento. Trata-se sobretudo do professor que abre o peito, descruzando os braços, que encara seu ofício como tarefa política, desejante e desejosa, ansiando à condução pela descoberta da cidadania.

Kirinus trabalhou fundamentalmente o "inatismo lingüístico do homem e sua natureza mito-poética" buscando re-significar o discurso advindo do mito, ou "mithos que em grego significa aquilo que se relata. 0 relato é linguagem". Não há como se esquivar dessa evidência, nem mesmo em tempos de pós-modernidade.

Para a autora, a sociedade pós-moderna e sua dinamicidade não suportam (aparentemente) o estático, o imóvel, "nem qualquer outro tipo de

* Mestranda do Programa de Pós- Graduação em Educação da PUCPR 
enquadramento. Ela é circularizante. E, no lugar da valorização apenas do objetivo final, aprecia também o processo, o percurso, o caminho".

A leitura deste livro, me parece, é indispensável para os que estão interessados em descobrir no pensamento de Bachelard da Poética do Espaço, de Carlos Drummond de Andrade, Maffesoli (só para citar alguns autores trabalhados por Kirinus), um possível caminho para afirmar a dimensão poética da linguagem como pano de fundo para uma Pedagogia do Bom Senso.

$\mathrm{O}$ engessamento da linguagem, para utilizar o termo bakhtiniano, denota a intencionalidade do achatamento afetivo/psicológico/intelectual do sujeito do conhecimento que sob a ordem do sistema escolar, a serviço das políticas institucionais, desmontam e destroem a nacionalidade brasileira exercitando a perversidade do culto ao medo do conhecimento. Sem xenofobismo barato mas resgatando a cidadania dos cidadãos brasileiros (e no caso de Kirinus, da Aménica Latina), permitir fluir o desejo de saber, permitir plenamente a fruição da dimensão de humanidade, dignidade e sobretudo de exercício da dimensão de sujeito históricos de nossos povos.

Neste trabalho, verifica-se a presença de Freinet no diálogo com os autores citados (dentre outros), chamando aos educadores para "o cantar, o descobrir, o relacionar, o inventar" tão fluídos na infância, voltem a fazer parte do processo educativo, no nível de ensino em que se encontre o sujeito educando.

É preciso vencer o medo do "lobo mau", chamado nestes tempos pós-modernos de discurso válido, rígido e, decididamente, mercadológico e informático. Na frase que muito chamou a atenção "o fascínio pelas palavras afeta indistintamente a todos os seres humanos".

Cantemo-la então. Desfraldemos seus reais significados. Apossemonos dela como famintos de conhecimento. 